\title{
BIMBINGAN BELAJAR TERHADAP HASIL BELAJAR MATEMATIKA
}

\section{TUTORING ON MATHEMATICS LEARNING OUTCOMES}

\author{
I Supriatna1, ND Yuliawati1a, dan W Firmansyah' ${ }^{1}$ \\ ${ }^{1}$ Program Studi Pendidikan Guru Sekolah Dasar, Fakultas Keguruan dan Ilmu Pendidikan, \\ Universitas Djuanda Bogor, Jl Tol Ciawi No. 1 Kotak Pos 35 Ciawi Bogor 16720 \\ a Korespondensi: Nanda Dwi Yuliawati, Email: nanda.dwi.yulawati.ndy@gmail.com \\ (Diterima: 25-11-2016; Ditelaah: 25-11-2016; Disetujui: 11-02-2017)
}

\begin{abstract}
Many students still consider mathematics difficult and tedious, thus effect on the learning outcomes of mathematics. This study aims to determine the influence of tutoring on mathematics learning outcomes with the object of study limited only to the tutoring as independent variable and mathematics learning outcomes as dependent variable. The methods used are observation, interview, questionnaire and documentation. Documentation is used to obtain the learning outcomes of mathematics by looking at the final grades of mathematics in the sixth grade. The research used sampling technique, population in the study were students of grade VI A and VI B as many as 47 students, and using samples from all populations. Instruments tested using validity test using Product Moment formula and reliability test using Alpha Cronbach obtained index of 0.702. The data obtained were analyzed using simple regression analysis. The regression equation obtained is $\mathrm{Y}=36,862+$ $0,541 \mathrm{X}$ which means the improvement of tutoring will be followed by the increase of mathematics learning outcomes, and has R Square 0,571 or $57,1 \%$ and $42,9 \%$ determined by other factors.
\end{abstract}

Keywords: learning outcomes, mathematics, tutoring.

\section{ABSTRAK}

Banyak siswa masih menganggap mata pelajaran matematika sulit dan menjenuhkan, sehingga berpengaruh terhadap hasil belajar matematika. Penelitian ini bertujuan untuk mengetahui pengaruh bimbingan belajar terhadap hasil belajar matematika dengan objek penelitian dibatasi hanya terhadap bimbingan belajar sebagai variabel bebas dan hasil belajar matematika sebagai variabel terikat. Metode yang digunakan adalah observasi, wawancara, angket dan dokumentasi. Dokumentasi digunakan untuk memperoleh hasil belajar matematika dengan melihat nilai ujian akhir semester matematika di kelas VI. Penelitian menggunakan teknik sampling, populasi dalam penelitian adalah siswa kelas VI A dan VI B sebanyak 47 siswa, dan menggunakan sampel dari semua populasi. Instrumen diuji menggunakan uji validitas menggunakan rumus Product Moment dan uji reliabilitas menggunakan Alpha Cronbach diperoleh indeks sebesar 0,702. Data yang diperoleh dianalisis menggunakan analisis regresi sederhana. Persamaan regresi yang diperoleh yaitu $\mathrm{Y}=36,862+0,541 \mathrm{X}$ yang berarti peningkatan bimbingan belajar akan diikuti dengan peningkatan hasil belajar matematika, dan memiliki nilai $R$ Square 0,571 atau $57,1 \%$ dan $42,9 \%$ ditentukan oleh faktor lain.

Kata kunci: bimbingan, hasil belajar, matematika.

Supriatna I, ND Yuliawati, dan W Firmansyah. 2017. Bimbingan belajar terhadap hasil belajar matematika. Didaktika Tauhidi Jurnal Pendidikan Guru Sekolah Dasar 4(1): 10-18. 


\section{PENDAHULUAN}

Globalisasi membuat kehidupan semakin kompetitif dan memaksa manusia untuk mencapai status dan taraf kehidupan yang lebih baik. Pendidikan hadir sebagai suatu hal yang sangat menentukan bagi perkembangan diri siswa untuk menghadapi globalisasi tersebut. Namun dalam setiap kegiatan pembelajaran selalu terdapat suatu permasalahan yang berhubungan dengan proses kegiatan belajar mengajar itu sendiri. Kesulitan atau hambatan dalam proses kegiatan belajar mengajar yang biasa ditemukan pada banyak siswa, seperti rendahnya hasil belajar dan lambatnya siswa dalam menangkap pelajaran terlebih lagi pada mata pelajaran matematika.

Matematika adalah salah satu mata pelajaran yang memiliki peranan penting, dengan jumlah jam pelajaran yang relatif lebih banyak dibandingkan dengan mata pelajaran lainnya. Meskipun begitu matematika masih dianggap sebagai mata pelajaran yang sulit dan menakutkan. Hal ini didukung data observasi hasil nilai Ujian Tengah Semester yang menunjukkan 22 dari 47 siswa kelas VI di SDN Cibalagung 5 belum lulus pada mata pelajaran matematika dilihat dari Kriteria Ketuntasan Minimum (KKM) pada kelas tersebut. Salah satu faktor penyebab kelemahan pada mata pelajaran matematika adalah ketidaksukaan siswa terhadap mata pelajaran matematika tersebut. Selain itu, siswa beranggapan bahwa matematika tidak dapat dimanfaatkan dalam kehidupan sehari-hari jika hanya berkutat dengan angka dan rumus.

Permasalahan yang ditemukan pada proses kegiatan belajar mengajar dipengaruhi oleh dua faktor yaitu faktor internal dan eksternal (Slameto 2010). Faktor internal atau dari dalam diri siswa contohnya banyak siswa yang menganggap matematika sulit dan akan berdampak pada turunnya motivasi siswa dalam mempelajarinya, dan faktor eksternal atau dari luar diri siswa seperti keadaan dalam keluarga atau di sekitar lingkungan rumah tinggal siswa.

Guru berperan penting dalam membantu proses pembelajaran dan menanggulangi kesulitan belajar siswa di sekolah, sehingga guru diharapkan dapat memberikan pengajaran tambahan secara aktif dan efektif dalam setiap kegitan pembelajaran. Selain itu, dapat memberikan motivasi terhadap siswa yang akan berdampak pada hasil belajar yang optimal (Juantika 2011).

Bimbingan perlu dilakukan karena termasuk ke dalam bagian terpenting yang dapat menunjang pendidikan. Bimbingan dibagi menjadi empat macam, yaitu bimbingan pribadi dan sosial, bimbingan karir, bimbingan keluarga dan bimbingan akademik. Bimbingan belajar termasuk ke dalam bimbingan akademik. Bimbingan memiliki makna pemberian bantuan kepada siswa yang dilakukan secara bertahap dan berhubungan satu sama lain supaya siswa tersebut memahami dirinya, sanggup mengarahkan dirinya dan dapat bertindak secara wajar (Yusuf dan Juantika 2011). Bimbingan belajar mampu meningkatkan hasil belajar siswa yang secara langsung akan berpengaruh terhadap prestasi siswa (Yuni 2006). Bimbingan sebagai suatu proses yang tak hanya untuk memperbaiki atau mengarahkan hasil belajar siswa atau dalam hal akademiknya saja, tetapi juga dapat membuat siswa menjadi pribadi yang aktif dalam lingkungan sosial.

Berdasarkan hasil wawancara dengan kedua wali kelas VI, bimbingan belajar 
diduga memiliki pengaruh yang signifikan terhadap hasil belajar siswa, dilihat dari peningkatan nilai beberapa siswa yang signifikan. Hal ini disebabkan proses bimbingan belajar sudah berjalan selama lima tahun dan mampu menjadikan SDN Cibalagung 5 menjadi sekolah dengan lulusan terbanyak masuk ke SMP Negeri, sehingga ini menjadi salah satu faktor yang menarik untuk diteliti guna mengetahui ada atau tidaknya pengaruh bimbingan belajar terhadap hasil belajar dalam mata pelajaran matematika di kelas VI.

\section{MATERI DAN METODE}

\section{Materi}

Bimbingan belajar merupakan suatu proses pemberian bantuan yang bertujuan agar siswa memahami segala sesuatu tentang dirinya terutama tentang kegiatan akademiknya untuk mencapai hasil yang diharapkan dan mencapai tingkat perkembangan yang optimal. Terdapat juga tujuan, fungsi, dan faktor yang mempengaruhi bimbingan tersebut, sedangkan hasil belajar matematika merupakan sesuatu yang dicapai seseorang setelah melakukan usaha belajar khususnya dalam mata pelajaran matematika dan dinyatakan dengan sebuah nilai yang menjadi tolak ukur dalam melihat kemampuan memahami mata pelajaran tersebut, dalam pembahasan hasil belajar matematika juga terdapat jenis dan faktor yang mempengaruhi hasil belajar.

Kedudukan bimbingan pada umumnya dianggap sebagai hal yang semata-mata masalah keduniawian saja, tetapi ternyata hal tersebut salah, karena suatu bantuan atau bimbingan ini termasuk suatu sedekah dalam pandangan Islam, pemberian bimbingan terdapat dalam surat Al-'Ashr ayat 1-3 yang menyinggung tentang saling menasehati, dengan kata lain menunjukan bahwa manusia harus selalu mendidik diri sendiri maupun orang lain, nasehat diibaratkan bimbingan dalam mencapai sesuatu yang optimal dalam Islam. Hal tersebut merupakan sikap yang sangat istimewa, sebagaimana yang tertera pula dalam surat Al-Mujadalah ayat 11 yang bermakna Allah mengatakan agar manusia selalu bertindak dan berbuat sesuai dengan landasan ilmu, karena Allah meninggikan derajat orang-orang yang berilmu dan mau berbagi.

\section{Metode}

\section{Lokasi dan Jenis Penelitian}

Penelitian dilakukan di SDN Cibalagung 5 Kota Bogor. Pendekatan yang digunakan dalam penelitian ini adalah pendekatan kuantitatif dengan jenis korelasi fungsional. Pendekatan kuantitatif menurut Emzir (2009) ialah suatu pendekatan penelitian yang secara primer menggunakan paradigma postpositivist dalam mengembangkan ilmu pengetahuan menggunakan strategi penelitian seperti eksperimen dan survei yang memerlukan data statistik. Jenis korelasi fungsional dipilih karena dinilai sesuai dengan tujuan penelitian, yaitu untuk mengetahui pengaruh antara variabel bimbingan belajar yang diberi simbol $\mathrm{X}$ terhadap variabel hasil belajar matematika yang disimbolkan dengan Y.

\section{Variabel Penelitian}

Terdapat dua variabel dalam penelitian ini, yaitu variabel bebas dan variabel terikat. Variabel bebas merupakan variabel yang mempengaruhi variabel terikat dalam penelitian ini yaitu bimbingan belajar yang ditandai dengan $\mathrm{X}$ dan variabel terikat merupakan inti dari permasalahan atau 
yang menjadi akibat karena adanya variabel bebas, dalam penelitian ini hasil belajar matematika ditandai dengan Y (Sugiyono 2015).

\section{Populasi dan Sampel}

Populasi dan sampel pada penelitian ini berjumlah sama, yaitu 47 siswa dari seluruh kelas VI SDN Cibalagung 5 Kota Bogor. Pengambilan sampel dilakukan dengan menggunakan teknik sampel jenuh dimana semua anggota populasi digunakan sebagai sampel. Hal ini umum dilakukan apabila jumlah populasi relatif sedikit (Sugiyono 2015).

\section{Teknik Pengumpulan Data}

Teknik pengumpulan data pada penelitian ini menggunakan beberapa teknik, yaitu observasi, wawancara, angket dan dokumentasi. Observasi dilakukan dengan teknik observasi pasif dimana peneliti hanya mengamati dan tidak terlibat langsung dengan kegiatan responden yang diobservasi. Selanjutnya wawancara dilakukan dengan menggunakan teknik wawancara tidak terstruktur. Wawancara dilakukan terhadap dua orang guru kelas VI SDN Cibalagung 5. Lalu angket yang digunakan pada penelitian ini dibuat berdasarkan beberapa indikator yang diperoleh dari fungsi bimbingan belajar yang baik dan selanjutnya skor angket dihitung menggunakan skala Likert yang digunakan untuk mengukur sikap, pendapat, dan persepsi seseorang atau sekelompok orang tentang fenomena sosial (Sugiyono 2015). Angket ini ditujukan kepada seluruh siswa kelas VI SDN Cibalagung 5. Teknik yang terakhir adalah teknik dokumentasi yang digunakan untuk memperoleh beberapa data sebagai pelengkap teknik observasi, seperti hasil
Ulangan Akhir Semester (UAS) dan berbagai informasi tentang sekolah.

\section{Instrumen Penelitian}

Instrumen yang digunakan dibuat dari beberapa indikator yang ditetapkan dari fungsi bimbingan yang baik seperti bimbingan belajar 1) membantu siswa memahami potensi dirinya; 2) membantu mencegah kesulitan belajar; 3) membantu siswa peka terhadap lingkungan sekitar; 4) menciptakan lingkungan belajar yang kondusif; 5) membantu menyalurkan minat dan bakat; 6) membantu siswa menyesuaikan diri secara dinamis, dengan 30 pernyataan ke arah positif, sehingga setiap satu indikator mendapatkan lima pernyataan. Untuk menguji validitas instrumen digunakan rumus korelasi product moment dari Karl Pearson, sedangkan rumus yang digunakan untuk uji reliabilitas adalah rumus Alpha dari Cronbach. Uji validitas digunakan untuk mendapatkan tingkat ketepatan antara data sesungguhnya dan data yang dikumpulkan peneliti, sedangkan uji reliabilitas digunakan untuk mengetahui tingkat reliabilitas suatu instrumen, meskipun digunakan berulang kali dapat menghasilkan data yang sama (Sugiyono 2015). Kedua uji tersebut dihitung menggunakan aplikasi SPSS 16.0. dengan syarat rhitung harus lebih besar dari $r_{\text {tabel }}$ ( $\mathrm{r}_{\text {hitung }}>\mathrm{r}_{\text {tabel }}$ ) untuk validitas dan ketentuan nilai Alpha Cronbach harus lebih besar dari 0,7 untuk uji reliabilitas (Arikunto 2013).

\section{Teknik Analisis Data}

Sebelum melakukan analisis data perlu dilakukan uji prasyarat analisis yang meliputi uji normalitas dan uji linieritas. Uji normalitas dilakukan dengan menggunakan uji Liliefors. Pengujian normalitas digunakan agar peneliti mengetahui apakah data 
variabel $\mathrm{X}$ dan variabel $\mathrm{Y}$ terdistribusi normal, dengan syarat apabila nilai signifikansi $>0,05$ maka data terdistribusi normal. Selanjutnya, uji linieritas digunakan untuk mengetahui linearitas kedua variabel, dengan syarat nilai signifikansi lebih dari 0,05 maka dikatakan dua variabel tersebut mempunyai hubungan yang linier begitu pula sebaliknya atau dengan menggunakan pengujian nilai $F_{\text {hitung }}$ dengan syarat $F_{\text {hitung }}<$ Ftabel berarti data linier dan begitu pula sebaliknya.

Analisis yang digunakan adalah analisis regresi sederhana, yang bertujuan untuk mengetahui ada atau tidaknya pengaruh antara variabel $\mathrm{X}$ dan variabel Y. Koefisien determinasi digunakan untuk mengetahui seberapa besar pengaruh variabel $\mathrm{X}$ terhadap variabel $\mathrm{Y}$, dengan melihat tabel Model Summary pada tabel $R$ Square. Uji signifikansi F dan uji signifikansi t dilakukan untuk mengetahui besarnya signifikansi pengaruh variabel $\mathrm{X}$ terhadap variabel $\mathrm{Y}$. Uji signifikansi $F$ dilakukan dengan cara membandingkan varian data terbesar dibagi varian data terkecil dengan syarat $\mathrm{F}_{\text {hitung }}>$ $F_{\text {tabel }}$ dengan tingkat signifikansi $<0,05$ (Supardi 2014). Sedangkan pada uji t, Ha diterima apabila thitung $>$ tabel dengan tingkat signifikansi $<0,05$. Semua perhitungan menggunakan aplikasi SPSS 16.0.

\section{HASIL DAN PEMBAHASAN}

\section{Hasil}

Data bimbingan belajar diambil dengan cara memberikan angket kepada seluruh siswa kelas VI SDN Cibalagung 5 yaitu sebanyak 47 siswa, angket dibuat dengan beberapa indikator yang telah ditetapkan, yaitu beberapa indikator bimbingan yang baik.
Berdasarkan Tabel 1 tentang hasil distribusi frekuensi angket bimbingan belajar diperoleh bentuk diagram garis pada Gambar 1. Skor tertinggi yang diperoleh yaitu sebesar 83 , skor terendah sebesar 42 dengan rata-rata 69,57 dan nilai standar deviasi sebesar 7,895 (Tabel 2).

Tabel 1 Hasil distribusi frekuensi angket bimbingan belajar

\begin{tabular}{ccrr}
\hline No & Nilai angket & Frekuensi & Presentase \\
\hline 1 & $42-47$ & 1 & $2,1 \%$ \\
2 & $48-53$ & 1 & $2,1 \%$ \\
3 & $54-59$ & 2 & $4,2 \%$ \\
4 & $60-65$ & 6 & $12,9 \%$ \\
5 & $66-71$ & 15 & $31,9 \%$ \\
6 & $72-77$ & 15 & $31,9 \%$ \\
7 & $78-83$ & 7 & $14,9 \%$ \\
Total & & 47 & $100 \%$ \\
\hline
\end{tabular}

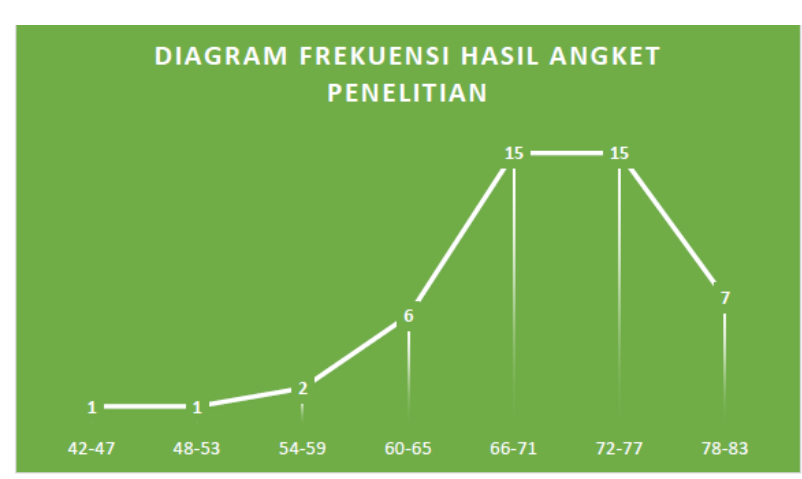

Gambar 1 Diagram frekuensi hasil angket penelitian

Hasil belajar matematika (variabel Y) diambil dari hasil Ulangan Akhir Semester (UAS) matematika siswa kelas VI di SDN Cibalagung 5 sebanyak 47 siswa yang disajikan dalam Tabel 3. Pada Tabel 3, frekuensi siswa yang mendapatkan nilai antara 70-72 ada 24 siswa atau sekitar $51,6 \%$ dan seterusnya. 
Tabel 2 Statistik deskriptif bimbingan belajar

\begin{tabular}{|c|c|c|c|c|c|c|c|c|}
\hline & $\mathbb{N}$ & Range & Minimum & Maximum & \multicolumn{2}{|c|}{ Mean } & Std. Deviation & Variance \\
\hline & Statistic & Statistic & Statistic & Statistic & Statistic & Std. Error & Statistic & Statistic \\
\hline$x$ & 47 & 41 & 42 & 83 & 69.57 & 1.152 & 7.895 & 62.337 \\
\hline Valid N (listwise) & 47 & & & & & & & \\
\hline
\end{tabular}

Hasil tersebut kemudian disajikan dalam bentuk diagram batang pada Gambar 2 . Selanjutnya berdasarkan Tabel 4 yang diperoleh dengan menggunakan SPSS 16.0, menunjukkan bahwa hasil belajar matematika tertinggi sebesar 88 , lalu nilai terendah sebesar 70, dengan rata-rata nilai sebesar 74,49 dalam tabel Mean, dan memiliki standar deviasi sebesar 5,653.

Adapun hasil uji normalitas dapat dilihat pada Tabel 5 (tabel Kolmogorov-Smirnov). Berdasarkan tabel tersebut menunjukkan bahwa data bimbingan belajar (variabel X) dan hasil belajar matematika (variabel Y) berdistribusi normal karena memiliki nilai signifikansi 0,111>0,05.

Selain uji normalitas, hasil dari uji linieritas yang diolah menggunakan SPSS 16.0 terdapat pada tabel Anova yang dapat dilihat pada Tabel 6. Tabel tersebut menunjukan nilai signifikansi $0,404>0,05$ dan memiliki nilai Fhitung sebesar 1,102 dan $F_{\text {tabel }}$ sebesar 4,061, sehingga $F_{\text {hitung }}<F_{\text {tabel }}$ maka dapat disimpulkan data bimbingan belajar (variabel $\mathrm{X}$ ) dan hasil belajar matematika (variabel Y) linier.
Tabel 3 Distribusi frekuensi hasil belajar matematika

\begin{tabular}{ccrr}
\hline No & Nilai UAS & Frekuensi & Presentase \\
\hline 1 & $70-72$ & 24 & $51,6 \%$ \\
2 & $73-75$ & 9 & $19 \%$ \\
3 & $76-78$ & 4 & $8,5 \%$ \\
4 & $79-81$ & 1 & $2 \%$ \\
5 & $82-84$ & 5 & $10,5 \%$ \\
6 & $85-87$ & 3 & $6,4 \%$ \\
7 & $88-90$ & 1 & $2 \%$ \\
Total & & 47 & $100 \%$ \\
\hline
\end{tabular}

Diagram Frekuensi Hasil Belajar Matematika

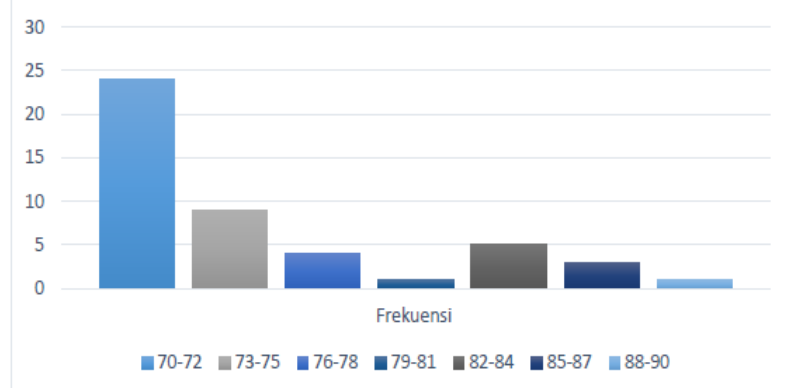

Gambar 2 Diagram frekuensi hasil belajar matematika

Tabel 4 Hasil statistik deskriptif hasil belajar matematika

\begin{tabular}{|l|r|r|r|r|r|r|r|r|}
\hline & \multicolumn{1}{|c|}{$\mathrm{N}$} & Range & Minimum & Maximum & \multicolumn{2}{|c|}{ Mean } & Std. Deviation & Variance \\
\cline { 2 - 9 } & Statistic & \multicolumn{1}{|c|}{ Statistic } & Statistic & \multicolumn{1}{c|}{ Statistic } & Statistic & Std. Error & \multicolumn{1}{c|}{ Statistic } & Statistic \\
\hline Y & 47 & 18 & 70 & 88 & 74.49 & .825 & 5.653 & 31.951 \\
Valid N (listwise) & 47 & & & & & & & \\
\hline
\end{tabular}


Tabel 5 Hasil uji normalitas

\begin{tabular}{|l|r|r|r|r|r|r|}
\hline \multirow{2}{*}{} & \multicolumn{3}{|c|}{ Kolmogorov-Smirnova $^{a}$} & \multicolumn{3}{c|}{ Shapiro-Wilk } \\
\cline { 2 - 7 } & Statistic & df & Sig. & Statistic & df & Sig. \\
\hline$X$ & .117 & 47 & .111 & .928 & 47 & .007 \\
\hline
\end{tabular}

a. Lilliefors Significance Correction

Tabel 6 Hasil uji linieritas

\begin{tabular}{|c|c|c|c|c|c|c|c|}
\hline & & & $\begin{array}{c}\text { Sum of } \\
\text { Squares }\end{array}$ & df & Mean Square & $\mathrm{F}$ & Sig. \\
\hline \multirow[t]{5}{*}{$\overline{Y * X}$} & \multirow{3}{*}{ Between Groups } & (Combined) & 692.495 & 21 & 32.976 & 1.061 & .440 \\
\hline & & Linearity & 7.210 & 1 & 7.210 & .232 & .634 \\
\hline & & Deviation from Linearity & 685.285 & 20 & 34.264 & 1.102 & .404 \\
\hline & \multicolumn{2}{|l|}{ Within Groups } & 777.250 & 25 & 31.090 & & \\
\hline & \multicolumn{2}{|l|}{ Total } & 1469.745 & 46 & & & \\
\hline
\end{tabular}

Berdasarkan hasil analisis regresi diperoleh persamaan regresi sebesar $\mathrm{Y}=$ $36,862+0,541 X$. Hal ini menunjukkan bahwa konstanta sebesar 36,862 menyatakan nilai a dan koefisien regresi $\mathrm{X}$ sebesar 0,541 menyatakan bahwa setiap penambahan 1 nilai $\mathrm{Y}$ maka nilai pada $\mathrm{X}$ bertambah. Hasil koefisien determinasi menunjukan bahwa pengaruh bimbingan belajar (variabel X) terhadap hasil belajar matematika (variabel Y) sebesar 0,571 atau $57,1 \%$ sedangkan $\quad 42,9 \% \quad$ sisanya dipengaruhi oleh variabel lain.

Uji signifikansi $\mathrm{F}$ dan uji signifikansi $\mathrm{t}$ dilakukan dengan menggunakan aplikasi Tabel 7 Hasil uji signifikansi (uji F)

\begin{tabular}{|ll|r|r|r|r|c|}
\hline Model & & Sum of & df & Mean Square & \multicolumn{1}{c|}{ F } & Sig. \\
\hline 1 & Regression & 838.692 & 1 & 838.692 & 59.807 & $.000^{a}$ \\
& Residual & 631.052 & 45 & 14.023 & & \\
& Total & 1469.745 & 46 & & & \\
\hline
\end{tabular}

a. Predictors: (Constant), $x$

b. Dependent Variable:

Tabel 8 Hasil uji signifikansi (uji t)

\begin{tabular}{|c|c|c|c|c|c|c|}
\hline \multirow{2}{*}{\multicolumn{2}{|c|}{ Model }} & \multicolumn{2}{|c|}{ Unstandardized Coefficients } & \multirow{2}{*}{$\begin{array}{c}\begin{array}{c}\text { Standardized } \\
\text { Coefficients }\end{array} \\
\text { Beta }\end{array}$} & \multirow[b]{2}{*}{$t$} & \multirow[b]{2}{*}{ Sig. } \\
\hline & & $\mathrm{B}$ & Std. Error & & & \\
\hline \multirow[t]{2}{*}{1} & (Constant) & 36.862 & 4.896 & & 7.529 & .000 \\
\hline & $x$ & .541 & .070 & .755 & 7.733 & .000 \\
\hline
\end{tabular}

a. Dependent Variable: $Y$

SPSS 16.0. Dari hasil uji $\mathrm{F}$ diperoleh nilai $F_{\text {hitung }}$ sebesar 59,807 dan nilai $F_{\text {tabel }}$ sebesar 4,061 dengan nilai sig. 0,000, sehingga Fhitung $\geq F_{\text {tabel }}$ (Tabel 7), maka terdapat pengaruh yang signifikan antara bimbingan belajar (variabel $\mathrm{X}$ ) dan hasil belajar matematika (variabel $\mathrm{Y}$ ). Uji $\mathrm{t}$ juga dilakukan untuk mengetahui tingkat signifikansi. Hasil uji t disajikan pada Tabel 8. Dari hasil uji $t$ diperoleh nilai thitung sebesar 7,733 dan nilai tabel sebesar 2,014 dengan nilai sig. 0,000, sehingga thitung $\geq$ ttabel, maka bimbingan belajar (variabel X) berpengaruh signifikan terhadap hasil belajar matematika (variabel Y). 


\section{Pembahasan}

Bimbingan belajar di SDN Cibalagung 5 sudah berjalan kurang lebih selama 5 tahun. Bimbingan kepada siswa kelas tinggi khususnya kelas VI dilakukan demi mempersiapkan kemampuan untuk mengikuti Ujian Nasional dan ujian-ujian lainnya. Bimbingan belajar di kelas VI dilaksanakan setiap hari senin sampai kamis pukul 13.00-15.00 WIB secara bervariasi. Mata pelajaran matematika selalu dipelajari di setiap pertemuan, karena mata pelajaran matematika merupakan mata pelajaran dengan nilai rata-rata terendah.

Setiap hari Senin kegiatan bimbingan belajar dimulai dengan mata pelajaran matematika dan bahasa Indonesia. Mata pelajaran matematika dibuka dengan membahas soal-soal yang belum tuntas dibahas pada saat kegiatan belajar mengajar berlangsung, selanjutnya melakukan tanya jawab, lalu setelah itu guru meminta siswa duduk secara berkelompok dan meminta siswa memecahkan sebuah permasalahan dengan mengerjakan soal. Selanjutnya pada hari Selasa dimulai dengan mata pelajaran IPA dan matematika. Pada mata pelajaran matematika dibuka kembali dengan membahas soal yang belum selesai dibahas pada kegiatan belajar mengajar, selanjutnya tanya jawab, lalu guru meminta siswa belajar secara mandiri dengan mengerjakan soal secara berkelompok dan ditambah dengan pemilihan tutor sebaya untuk mengerjakan soal secara bersama-sama. Pada hari Rabu dan Kamis kegiatan bimbingan belajar tidak jauh berbeda dari hari sebelumnya yaitu membahas soal, tanya jawab dan kerja kelompok. Akan tetapi pada hari Kamis, selain kegiatan yang dilakukan pada hari sebelumnya juga ditambah dengan evaluasi pada akhir pertemuan tentang apa saja yang telah dipelajari selama hari Senin sampai Kamis. Bimbingan belajar yang diberikan tidak hanya terpaku pada masalah belajar saja, tetapi juga pemberian beberapa pengetahuan tentang lingkungan dan pendidikan moral mengingat kelas VI adalah masa transisi dari anak-anak ke remaja.

Hasil Penelitian di SDN Cibalagung 5 berupa data bimbingan belajar (variabel X) diperoleh menggunakan angket dan melewati uji validitas dan uji reliabilitas. Sebelumnya pernyataan angket yang berjumlah 30 pernyataan diuji dengan uji validitas dan diperoleh 20 pernyataan yang valid. Pernyataan tersebut digunakan semua dalam pengujian selanjutnya. Berdasarkan uji reliabilitas dengan menggunakan teknik Alpha Cronbach diperoleh nilai reliabilitas $0,702>0,7$ yang berarti pernyataan tersebut reliabel, dengan skor rata-rata 69,57 dari 47 responden yaitu seluruh siswa kelas VI di SDN Cibalagung 5. Data hasil belajar matematika (variabel Y) diambil dari hasil UAS siswa kelas VI, dengan rata-rata yang cukup baik yaitu sebesar 74,49.

Berdasarkan hasil penghitungan menggunakan aplikasi SPSS 16.0 kedua variabel $\mathrm{X}$ dan $\mathrm{Y}$ memiliki nilai signifikansi sebesar 0,111 untuk uji normalitas yang berarti data tersebut berdistribusi normal karena $0,111>0,05$, sedangkan untuk uji linieritas memiliki nilai signifikansi sebesar 0,404 > 0,05 menunjukkan bahwa data tersebut linier. Bentuk persamaan regresi dalam penelitian ini diperoleh sebesar $\mathrm{Y}=$ $36,862+0,541 \mathrm{X}$ yang berarti jika nilai bimbingan belajar bertambah maka hasil belajar juga akan bertambah sebesar 0,541. Nilai $R$ Square sebesar 0,571 menunjukkan bahwa bimbingan belajar (variabel $\mathrm{X}$ ) berpengaruh terhadap hasil belajar matematika (variabel Y).

Bimbingan belajar dapat berpengaruh terhadap hasil belajar siswa dan akan 
membuat siswa terbiasa dapat mengarahkan dirinya sendiri baik dalam kegiatan belajar maupun kegiatan sosialnya sehari-hari. Hal ini sesuai dengan teori bimbingan yang dikemukakan oleh Gistod yang menyatakan bahwa bimbingan dan konseling merupakan proses yang berorientasi pada belajar, belajar untuk memahami diri sendiri, karena pada dasarnya siswa dituntut untuk memahami dirinya sendiri, memecahkan masalah, belajar mengembangkan pemahaman, tingkah laku dan sikap-sikap baru, dengan bimbingan yang berorientasi pada belajar siswa dapat memperoleh perkembangan ke arah yang lebih baik, yang diperoleh dari hasil belajar (Yusuf dan Juantika 2011).

\section{KESIMPULAN DAN IMPLIKASI}

\section{Kesimpulan}

Berdasarkan hasil analisis menunjukkan bahwa terdapat pengaruh yang signifikan pada bimbingan belajar terhadap hasil belajar matematika siswa kelas VI SDN Cibalagung 5. Hal ini ditunjukkan oleh nilai thitung $>$ ttabel, thitung sebesar 7,733 sedangkan tabel sebesar 2,014 pada taraf signifikansi 0,05 atau $5 \%$. Selain itu, berdasarkan hasil analisis regresi diperoleh persamaan regresi $\mathrm{Y}=36,862+0,541 \mathrm{X}$ yang berarti bahwa setiap peningkatan bimbingan belajar akan diikuti peningkatan hasil belajar matematika siswa. Besarnya pengaruh bimbingan belajar terhadap hasil belajar matematika adalah $57,1 \%$ dan sisanya sekitar 42,9\% dipengaruhi oleh variabel lain.

\section{Implikasi}

Efek dari hasil penelitian yang diperoleh diharapkan dapat meningkatkan mutu pendidikan dan digunakan sebagai dasar atau arahan kepada siswa agar dapat mengetahui cara menanggulangi kesulitan belajar yang dihadapi, dan juga sebagai acuan untuk guru dan sekolah agar melaksanakan bimbingan belajar bagi siswa yang benar-benar membutuhkan dan menjadikan bimbingan belajar yang sudah berjalan menjadi lebih baik lagi.

\section{DAFTAR PUSTAKA}

Arikunto S. 2013. Prosedur penelitian suatu pendekatan praktik. Edisi Pertama. Rineka Cipta, Jakarta.

Emzir. 2009. Metodologi penelitian pendidikan, kuantitatif, dan kualitatif. Grafindo Persada, Jakarta.

Juantika A. 2011. Bimbingan dan konseling dalam berbagai latar kehidupan. Edisi Pertama. Refika Aditama, Bandung.

Slameto. 2010. Belajar dan faktor-faktor yang mempengaruhinya. Rineka Cipta, Jakarta.

Sugiyono. 2015. Metode penelitian pendidikan. Edisi Ketiga. Alfabeta, Bandung.

Supardi. 2014. Aplikasi statistika dalam penelitian. Edisi Pertama. Ufuk Semesta, Jakarta.

Yuni I. 2006. Layanan bimbingan belajar untuk SD. Jurnal Pendidikan FIP UNY Volume 03 Nomor 03: 22-32.

Yusuf S dan NA Juantika. 2011. Landasan bimbingan konseling. Edisi Pertama. Remaja Rosda Karya, Bandung. 